\title{
RED CELL CHOLINESTERASE IN INFANCY AND CHILDHOOD*
}

\author{
BY \\ DAVID BURMAN $\dagger$ \\ From the Hospital School for Handicapped Children, State University of Iowa, U.S.A.
}

(RECEIVED FOR PUBLICATION NOVEMBER 30, 1960)

Little information is available on the erythrocyte cholinesterase levels in infancy and childhood. Sabine (1955) found it to be within the normal adult range for 18 children aged 3 months to 18 years, but in seven infants under 15 days of age the values varied from 57 to $75 \%$ of the mean adult value. Oka (1954) found a mean level similar to adults in 12 children aged 4 to 14 . Jones and McCance (1949) estimated the red cell cholinesterase in the cord blood of 24 infants and compared it to that in 11 adults. The mean cord blood level was $61 \%$ of the adult mean. Pritchard and Weisman (1956) obtained a similar result in their 16 cases.

This paper adds further data about infants and children and shows that the immature cells in cord blood contain more cholinesterase. However, even in severe erythroblastosis foetalis the level was not above the normal range.

The method of estimating red cell cholinesterase and its range in normal adults has been described previously (Burman, 1961).

\section{Observations}

The red cell cholinesterase was determined on blood from 58 children aged 2 to 19 years seen at the Hospital School. All these children had a mean corpuscular haemoglobin concentration above $30 \%$, and most of them suffered from a chronic neurological disorder for which they were having inpatient care. The mean and standard deviation of the 58 cases was $9.57 \pm 1.06$ units per ml. red blood cells with a standardized range (mean \pm 2 S.D.) of 7.45 to 11.69 units. There was no significant difference between the sexes and no correlation with age (Fig. 1). The negative correlation with haemoglobin content $(r=-0 \cdot 3010)$ was significant at the $5 \%$ level and with the mean corpuscular haemoglobin concentration $(\mathrm{r}=$ $-0 \cdot 3614)$ at the $1 \%$ level.

* This work formed part of an M.D. Thesis for the University of London.

$\dagger$ Present address: Paediatric Unit, St. Mary's Hospital, London,
Twenty infants under the age of 2 were studied. These infants were in-patients of the nursery of the Paediatric Department of the University Hospitals, Iowa City, and suffered from a variety of diseases. Many of them were anaemic with a low mean corpuscular haemoglobin concentration. The age distribution of these infants is shown in Fig. 2. No case aged 5 months or more had an activity below the normal adult range and no case aged 2 months or less had an activity higher than normal cord blood.

Samples of cord blood were collected from 57 normal babies born in the Obstetric Unit of the University Hospitals between January and April 1959. These infants were all singletons delivered per vaginam and all had a negative direct Coombs' test. No abnormality was detected during their stay of about five days in the newborn nursery. Of the 57 specimens, 27 had clotted. No difference was found between the mean red cell cholinesterase content of the clotted and successfully heparinized specimens $(\mathrm{t}=0.551)$. The mean cholinesterase activity of the 57 cases was $5 \cdot 29$ units per ml. red cells with a standard deviation of 1.09 units and a standardized range of $3 \cdot 11$ to $7 \cdot 47$ units. The distribution of these 57 observations is shown as

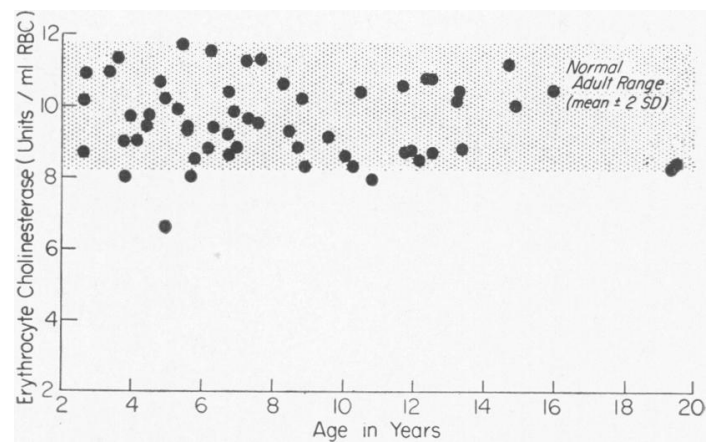

Fig. 1.-Red cell cholinesterase activity in 58 children aged 2 to 19 years without haematological disease. 


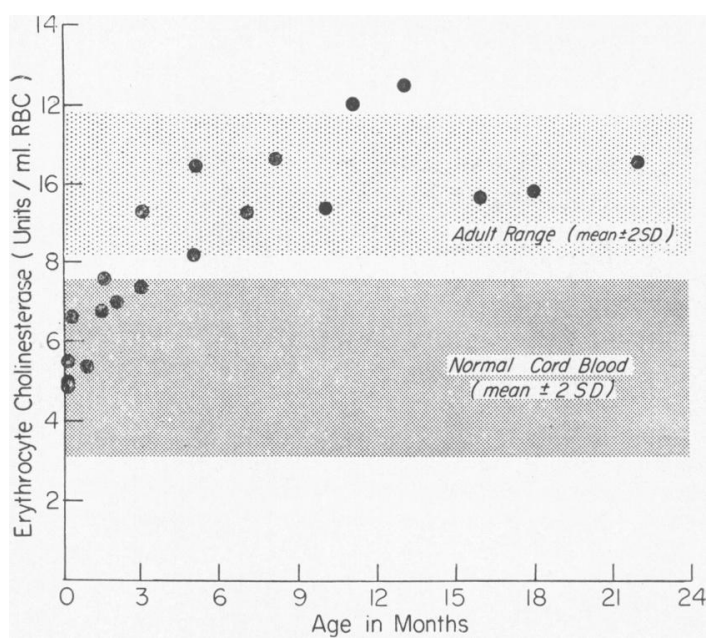

FIG. 2.-Red cell cholinesterase activity in 20 sick infants.

a histogram in Fig 3 and is 'normal'. There is no difference between the sexes and no correlation with birth weight, haemoglobin concentration, packed cell volume, reticulocyte count and normoblasts per c.mm. The negative correlation with the mean corpuscular haemoglobin concentration $(\mathrm{r}=-0.3949)$ was significant at the $5 \%$ but not the $2 \%$ level.

Partial haemolysis of cord red cells was performed by adding $1 \mathrm{ml}$. washed red cells (packed cell volume $=$ about 0.50 ) to $5 \mathrm{ml}$. 0.36 or $0.32 \%$ saline. The mixture was inverted five times and allowed to stand for 10 minutes. The cells resistant to haemolysis were then washed twice with physiological saline and their cholinesterase content determined. The degree of haemolysis was estimated by comparing the haemoglobin concentration of the supernatant with that of a similar tube in which complete haemolysis had been produced by distilled water. In view of the changes in red cell volume which occur when red cells are exposed to hypotonic saline, the cholinesterase is measured in terms of haemoglobin. The results of six experiments are shown in Table 1 . The cholinesterase after haemolysis was higher in every case. The mean difference of the six observations before and after haemolysis was 6.32 units. This can be compared with the experimental error of the estimation by a ' $t$ ' test. The standard deviation of the difference of two estimations due to experimental error was calculated by multiplying the standard deviation of duplicate estimations $(0.72$ units per gram haemoglobin) by the square root of 2 . The value of ' $t$ ' was $6 \cdot 2083$. With 5 degrees of freedom,

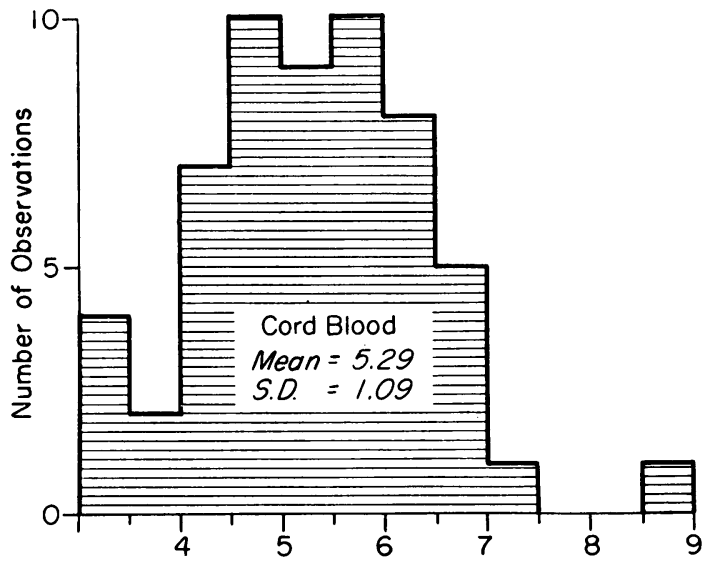

Red Cell Cholinesterase (Units/ml. Red Cells)

FIG. 3.-The distribution of the red cell cholinesterase activity in cord blood from 57 normal infants.

this is significant at the $1 \%$ level. The correlation between the percentage of haemolysis and the increase in red cell cholinesterase $(r=+0.8134)$ is significant at the $5 \%$ level.

The red cells were separated by centrifuging the heparinized blood at 3,000 r.p.m. $(1,500$ g.) for 10 minutes. The top and bottom layers were then separated and each layer washed three times in physiological saline. The cholinesterase was estimated on both samples and a specimen of washed red cells which had not been centrifuged. The cholinesterase was measured in terms of haemoglobin because centrifuging separates cells of different densities and different volumes. The results of five experiments are shown in Table 2. The cholinesterase of the cells in the upper layer was higher than that before centrifuging in every case. The mean difference was $3 \cdot 20$ units and this differed significantly from the experimental error $(t=3 \cdot 1434$; $\mathrm{df}=4 ; \mathrm{p}<0.05)$. The mean cholinesterase of

TABLE 1

EFFECT OF PARTIAL HAEMOLYSIS OF ERYTHROCYTES FROM CORD BLOOD UPON CHOLINESTERASE CONTENT OF CELLS WHICH ARE NOT HAEMOLYSED

\begin{tabular}{|c|c|c|c|c|c|}
\hline \multirow[b]{2}{*}{$\begin{array}{l}\text { Case } \\
\text { No. }\end{array}$} & \multirow{2}{*}{$\begin{array}{c}\text { Strength } \\
\text { of } \\
\text { Saline }\end{array}$} & \multirow{2}{*}{$\begin{array}{c}\text { Degree } \\
\text { of } \\
\text { Haemo- } \\
\text { lysis } \\
(\%)\end{array}$} & \multicolumn{3}{|c|}{ Cholinesterase (units per g. Hb) } \\
\hline & & & $\begin{array}{c}\text { Before } \\
\text { Haemo- } \\
\text { lysis }\end{array}$ & $\begin{array}{c}\text { After } \\
\text { Haemo- } \\
\text { lysis }\end{array}$ & Difference \\
\hline $\begin{array}{l}1 \\
2 \\
3 \\
4 \\
5 \\
6\end{array}$ & $\begin{array}{l}0 \cdot 36 \\
0 \cdot 36 \\
0 \cdot 36 \\
0 \cdot 32 \\
0 \cdot 36 \\
0 \cdot 32\end{array}$ & $\begin{array}{l}46 \\
54 \\
21 \\
73 \\
49 \\
67\end{array}$ & $\begin{array}{l}17 \cdot 3 \\
21 \cdot 3 \\
16 \cdot 9 \\
22 \cdot 7 \\
21 \cdot 0 \\
21 \cdot 0\end{array}$ & $\begin{array}{l}24 \cdot 2 \\
25 \cdot 7 \\
20 \cdot 9 \\
31 \cdot 4 \\
26 \cdot 8 \\
29 \cdot 1\end{array}$ & $\begin{array}{l}6 \cdot 9 \\
4 \cdot 4 \\
4 \cdot 0 \\
8 \cdot 7 \\
5 \cdot 8 \\
8 \cdot 1\end{array}$ \\
\hline
\end{tabular}


TABLE 2

CHOLINESTERASE CONTENT OF RED CELLS OF CORD BLOOD AFTER CENTRIFUGAL SEGREGATION

\begin{tabular}{|c|c|c|c|}
\hline Case No. & Fraction & $\begin{array}{c}\text { Red Cell } \\
\text { Cholinesterase } \\
\text { (units per g. Hb) }\end{array}$ & Difference \\
\hline 1 & $\begin{array}{l}\text { Upper } \\
\text { Unseparated } \\
\text { Lower }\end{array}$ & $\begin{array}{l}17 \cdot 2 \\
14 \cdot 7 \\
13 \cdot 5\end{array}$ & $\begin{array}{l}+2 \cdot 5 \\
-1 \cdot 2\end{array}$ \\
\hline 2 & $\begin{array}{l}\text { Upper } \\
\text { Unseparated } \\
\text { Lower }\end{array}$ & $\begin{array}{l}23 \cdot 9 \\
19 \cdot 7 \\
20 \cdot 0\end{array}$ & $\begin{array}{l}+4 \cdot 2 \\
+0.3\end{array}$ \\
\hline $3 *$ & $\begin{array}{l}\text { Upper } \\
\text { Unseparated } \\
\text { Lower }\end{array}$ & $\begin{array}{l}21 \cdot 3 \\
17 \cdot 6 \\
13 \cdot 4\end{array}$ & $\begin{array}{l}+3 \cdot 7 \\
-4 \cdot 2\end{array}$ \\
\hline 4 & $\begin{array}{l}\text { Upper } \\
\text { Unseparated } \\
\text { Lower }\end{array}$ & $\begin{array}{l}19 \cdot 7 \\
18 \cdot 2 \\
17 \cdot 7\end{array}$ & $\begin{array}{l}+1.5 \\
-0.5\end{array}$ \\
\hline 5 & $\begin{array}{l}\text { Upper } \\
\text { Unseparated } \\
\text { Lower }\end{array}$ & $\begin{array}{l}23 \cdot 8 \\
19 \cdot 7 \\
19 \cdot 8\end{array}$ & $\begin{array}{l}+4 \cdot 1 \\
+0 \cdot 1\end{array}$ \\
\hline
\end{tabular}

* Case of erythroblastosis foetalis.

the lower layer was 0.90 units less than the mean of the unsegregated samples; this difference was not significant $(\mathrm{t}=0.8841)$. In two cases the lower layer had more cholinesterase than the original specimen, but these differences were within experimental error.

The cord blood from 11 cases of erythroblastosis foetalis was studied. Nine of these cases were due to $\mathrm{Rh}$ incompatibility and two to $\mathrm{ABO}$ incompatibility. In all the $\mathrm{Rh}$ cases, the mother's serum contained antibodies and the direct Coombs' test was positive in cord blood. All the cases had at least one exchange transfusion except one case

TABLE 3

RED CELL CHOLINESTERASE IN NINE CASES OF ERYTHROBLASTOSIS DUE TO RH AND TWO TO ABO INCOMPATIBILITY

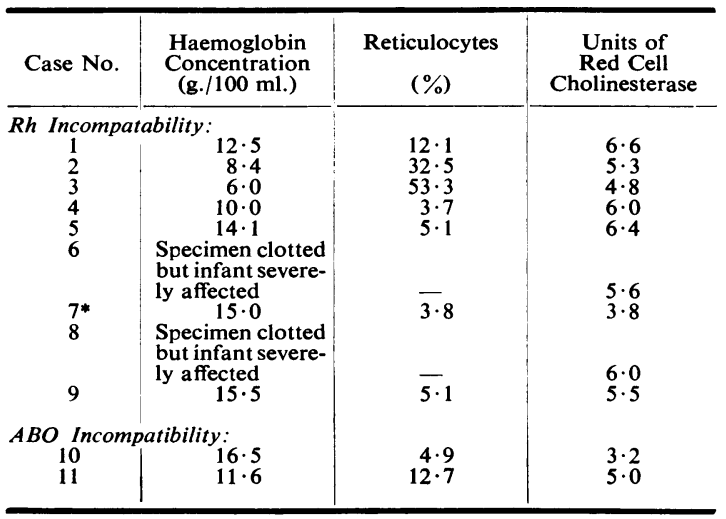

* Required no treatment. which required no treatment. ABO haemolytic disease was diagnosed if the mother was group $O$ and the infant A or B, if the mother's serum contained a haemolysin against adult A or B cells, and if the infant showed signs of excessive haemopoiesis and developed jaundice within 24 hours of birth. The results of the 11 cases are shown in Table 3 . All the values of erythrocyte cholinesterase were within the normal range. Of the nine cases due to $\mathrm{Rh}$ incompatibility only two were below the normal mean and one of these was the mildly affected infant who required no treatment. The mean cholinesterase content of the nine cases of haemolytic disease was 5.56 units per $\mathrm{ml}$. red cells, but this is not significantly higher than the mean for normal cord blood.

\section{Discussion}

With the same method of estimating red cell cholinesterase, the mean and standard deviation in 71 haematologically normal adults is $9.96 \pm 0.90$ units (Burman, 1961). These figures do not differ significantly from those found for the 58 children reported here. The two series can therefore be combined and the mean of the 129 observations is $9 \cdot 78$ units with a standard deviation of 0.97 . The red cell cholinesterase in cord blood is lower than in adults and only one case lies within the adult range. The mean cord blood level is $53 \%$ of the adult mean. This figure is in general agreement with, although a little lower than that found by Jones and McCance (1949), Sabine (1955) and Pritchard and Weisman (1956). The data in infancy recorded here are not reliable as many of the infants studied were both ill and anaemic, but the adult blood level appears to be reached between 3 and 5 months of age and this agrees with the scanty data of Sabine (1955). It is at about this age that the red cell population changes from foetal cells to those produced after birth, so it is probable that the low cholinesterase content of cord cells reflects a difference between foetal and post-natal red cells.

Cells which are relatively resistant to haemolysis have been shown to be young cells (Marks and Johnson, 1958). If whole blood is centrifuged, the top layer contains the younger cells (Borun, Figueroa and Perry, 1957). Both these manoeuvres with cord blood show that young cells contain more cholinesterase than mature cells and with partial haemolysis the rise in cholinesterase is proportional to the degree of haemolysis. Similar results have been found in human adults by Allison and Burn (1955) and in adult rats by Pritchard (1949). Many clinical observations also suggest that young cells 
contain increased quantities of cholinesterase for a high level is often found when there is a reticulocytosis (Meyer, Sawitsky, Ritz and Fitch, 1948; Sabine, 1951; Scudamore, Vorhaus and Kark, 1951; Sabine, 1959). In these circumstances, the red cell cholinesterase should be increased in erythroblastosis foetalis, but this was not observed in the 11 cases studied, although several were severely affected with high reticulocyte counts.

\section{Summary}

The mean cord blood red cell cholinesterase is only $53 \%$ of the adult mean. The adult level is reached between 3 and 5 months of age. Young cord red cells contain more cholinesterase than older cells. In 11 cases of erythroblastosis foetalis the red cell cholinesterase was within the normal cord blood range.

I am grateful to Dr. R. R. Rembolt for continual help and encouragement during this investigation.
REFERENCES

Allison, A. C. and Burn, G. P. (1955). Enzyme activity as a function of age in the human erythrocyte. Brit. J. Haemat., 1, 291.

Borun, E. R., Figueroa, W. G. and Perry, S. M. (1957). The distribution of $\mathrm{Fe}^{59}$ tagged human erythrocytes in centrifuged specimens as a function of cell age. J. clin. Invest., 36, 676.

Burman, D. (1961). An electrometric method for the estimation of red cell cholinesterase. In the press.

Jones, P. E. H. and McCance, R. A. (1949). Enzyme activities in the blood of infants and adults. Biochem. J., 45, 464.

Marks, P. A. and Johnson, A. B. (1958). Relationship between the age of human erythrocytes and their osmotic resistance: a basis for separating young and old erythrocytes. J. clin. Invest. 37, 1542 .

Meyer, L. M., Sawitsky, A., Ritz, N. D. and Fitch, H. M. (1948). A study of cholinesterase activity of the blood of patients with pernicious anemia. J. Lab. clin. Med., 33, 189.

Oka, M. (1954). Studies on the cholinesterase activity of red cell plasma and synovial fluid with special reference to rheumatic diseases. Acta med. scand., Supplement 293.

Pritchard, J. A (1949). Erythrocyte age and cholinesterase activity. Amer. J. Physiol., 158, 72.

- and Weisman, R., Jr. (1956). Erythrocyte cholinesterase activity in normal pregnancy and in megaloblastic and other anemias of pregnancy and the puerperium. J. Lab. clin. Med. 47, 98 .

Sabine, J. C. (1951). The cholinesterase of erythrocytes in anemias. Blood, 6, 151.

(1955). The clinical significance of erythrocyte cholinesterase titers. 1. A method suitable for routine clinical use, and the titers. 1. A method suitable for routine clinical
distribution of normal values. Ibid., 10, 1132 . (1959). Erythrocyte cholinesterase titers in hematologic disease states. Amer. J. Med., 27, 81 .

Scudamore, H. H., Vorhaus, L. J., II and Kark, R. M. (1951). Observations on erythrocyte and plasma cholinesterase activity in dyscrasias of the blood. Blood, $6,1260$. 